\title{
ANALISIS EFEKTIVITAS PENAGIHAN RETRIBUSI PERSAMPAHAN DAN KONTRIBUSINYA TERHADAP PENDAPATAN ASLI DAERAH KOTA TOMOHON
}

\author{
Juanda Elia Rembet ${ }^{1}$, Jantje J. Tinangon ${ }^{2}$, Treesje Runtu ${ }^{3}$ \\ 1,2,3 Jurusan Akuntansi, Fakultas Ekonomi dan Bisnis, Universitas Sam Ratulangi, Jl. Kampus Bahu, Manado, \\ 95115, Indonesia \\ E-mail : junrembet1@gmail.com
}

\begin{abstract}
Regional Original Revenue (PAD) is regional revenue derived from local taxes, regional retribution, and management of separated regional assets, as well as other legitimate regional income. Regional levies are one of the sources of financing regional development in supporting the implementation of regional autonomy. One type of regional retribution collected by the Tomohon City Government is waste retribution. This study aims to analyze the effectiveness of waste collection fees in Tomohon City, and the contribution of solid waste retribution to PAD. In this study using quantitative descriptive method. The analysis data used in this study is the analysis of contribution and effectiveness. The results of the receipt effectiveness of solid waste levies in 2015-2016 was not effective and decreased, then in 2017 although it was still ineffective but experienced a very drastic increase. The contribution of solid waste retribution to regional retribution is still relatively small in 2015 and 2016 but in 2017 its contribution is very significant to regional retribution. While the contribution of solid waste retribution to the PAD of Tomohon City in 2015-2017 is very small for the past 3 years. Leaders of Regional Revenue Service and the Environmental Agency should continue to optimize the receipt of solid waste fees with intensification \& extensification, so that there will always be changes on the system of receiving regional retribution towards a better direction.
\end{abstract}

Keywords: effectivity, contribution, local government income

\section{PENDAHULUAN}

Populasi penduduk Kota Tomohon yang terus meningkat, serta aktifitas bisnis di Kota Tomohon yang semakin berkembang mengakibatkan jumlah sampah juga meningkat, sehingga Pemerintah Kota Tomohon menjawab keluhan masyarakat tersebut lewat layanan persampahan melalui Peraturan Daerah Nomor 8 Tahun 2012. Jika dilihat dari keadaan tersebut retribusi persampahan harusnya menjadi salah satu sumber Pendapatan Asli Daerah atau disingkat PAD. Karena saat ini Kota Tomohon hampir setiap hari ada truk atau motor yang mengangkut sampah, sehingga penulis ingin mengetahui apakah masyarakat taat dalam membayar retribusi persampahan kepada pemerintah, dan ada juga orang-orang tidak bertanggung jawab yang melakukan penggelapan sehingga mengakibatkan pemungutan retribusi persampahan tidak maksimal. Untuk memaksimalkan PAD Kota Tomohon khususnya retribusi persampahan pemerintah daerah harus terus mengevaluasi efektivitas penerimaan retribusi persampahan, dengan maksud untuk melihat apakah selama ini penerimaan retribusi persampahan sudah efektif atau belum.

\section{TINJAUAN PUSTAKA}

Konsep Akuntansi. Menurut Kartikahadi, dkk. (2016:3) menyatakan akuntansi tujuannya melaporkan hasil informasi untuk pihak-pihak yang membutuhkan dalam bentuk sistem informasi keuangan. 
Konsep Akuntansi Perpajakan. Pengertian Akuntansi Perpajakan menurut Sukrisno Agoes (2014: 10) adalah akuntansi pajak ialah penerapannya sesuai dengan peraturan tentang perpajakan yang ada.

Pengertian Pajak. Menurut Sari (2013:34) pajak adalah iuran terutang masyarakat kepada negara yang dapat dipaksakan dan wajib membayarnya menurut Undang-undang dalam penyelenggaraan pemerintah yang berfungsi membiayai pengeluaran umum.

Fungsi Pajak. Sari (2013: 37) menyatakan pajak mempunyai dua fungsi utama yakni fungsi penerimaan atau budgetair yang artinya sebagai sumber pendapatan negara pajak berfungsi untuk membiayai pengeluaran-pengeluaran negara, kemudian yang kedua adalah fungsi mengatur (Regulerend), dengan ini pajak bisa digunakan sebagai alat untuk mencapai tujuan. Pelaksanaan fungsi ini bisa negatif atau positif.

Jenis-Jenis Pajak. Resmi (2014: 7) membedakan jenis pajak terbagi atas tiga yaitu, menurut golongan yang terdiri atas pajak langsung dan pajak tidak langsung, kemudian menurut sifat yang terdiri atas pajak subjektif juga pajak objektif, lalu yang terakhir menurut lembaga yang terdiri dari pajak negara beserta pajak daerah.

Asas Pemungutan Pajak. Waluyo (2013: 13) menyatakan bahwa asas pemungutan pajak terdiri dari : (1) equality; (2) certainty; dan (3) economy

Syarat Pemungutan Pajak. Mardiasmo (2016:2) berpendapat bahwa ada 5 syarat yang harus dipenuhi agar pemungutan pajak berjalan mulus yaitu:

1. Adil dalam pemungutan (syarat keadilan)

2. Undang-undang menjadi dasar pemungutan (syarat yudiris)

3. Perekonomian tidak terganggu (syarat ekonomis)

4. Efisien dalam pemungutan pajak (syarat finansial)

5. Sederhana dalam sistem pemungutan .

Sistem Pemungutan Pajak. Resmi (2014:11) mengemukakan bahwa dalam memungut pajak ada 3 sistem pemungutan pajak yang bisa digunakan, yaitu Official Assessment System, Self Assessment System, dan With Holding System.

Konsep Pendapatan Asli Daerah. Pendapatan Asli Daerah atau PAD berarti seluruh penambahan nilai kekayaan bersih atau semua hak daerah yang diakui dalam periode tahun anggaran bersangkutan Menurut Pasal 1 ayat 15 Undang-undang Nomor 23 tahun 2004 tentang Pemerintahan Daerah.

Konsep Retribusi Daerah. Pengertian Retribusi Daerah yakni pungutan daerah atas jasa yang telah diberikan oleh daerah terhadap pemakaian jasa, usaha atau milik daerah bagi yang berkepentingan.

Peraturan Pemerintah Tentang Retribusi Daerah. Retribusi Daerah sudah diatur dalam peraturan yakni tertuang dalam Undang-Undang No. 28 Tahun 2009.

Tarif Retribusi Daerah. Mardiasmo (2016: 35) mengemukakan yakni cara mengalikan tarif retribusi dengan tingkat penggunaan jasa itulah yang harus dihitung untuk mengetahui seberapa besar retribusi terutang dari orang pribadi/badan yang menggunakan jasa retribusi dari pemerintah. Maka besarnya retribusi terutang dapat dihitung dari tarif retribusi dan tingkat penggunaan jasa.

Retribusi Persampahan. Menurut Peraturan Daerah Kota Tomohon No. 8 Tahun 2012 tentang retribusi pelayanan persampahan/kebersihan, yang selanjutnya disebut retribusi adalah pembayaran atas penyelenggaraan pelayanan persampahan/kebersihan.

Tarif Retribusi Persampahan Berdasarkan Objek Retribusi di Kota Tomohon. Berdasarkan Perda. Kota Tomohon No. 8 Tahun 2012, besarnya tarif retribusi persampahan di Kota Tomohon dibayar perbulan juga dibedakan berdasarkan objek.

Konsep Efektivitas. Mahmudi (2016:143) menyatakan bahwa efektivitas adalah hubungan antara keluaran dengan sasaran atau tujuan yang harus dicapai. Dapat dikatakan 
efektif jika suatu proses atau kegiatan dapat mencapai tujuan dan sasaran akhir kebijakan. Retribusi persampahan dapat dikategorikan tingkat efektivitasnya mulai dari pencapaian di atas $100 \%$ artinya sangat efektif, perolehan diantara $90 \%-100 \%$ artinya efektif, pencapaian antara $80 \%$ - 90\% artinya cukup efektif, perolehan diantara $60 \%-80 \%$ artinya kurang efektif dan pencapaian di bawah $60 \%$ artinya tidak efektif.

Kontribusi. Kontribusi adalah suatu besar sumbangsih terhadap suatu hal atau kegiatan yang terlaksana (Handoko, 2013:3).

Penelitian Terdahulu. Ada penelitian-penelitian sebelumnya yang dijadikan bahan pertimbangan dalam melakukan penelitian pada PAD Kota Tomohon, penelitian yang dilakukan oleh Saifullah (2016) terkait Efektifitas Peningkatan Retribusi Sampah Terhadap Pencapaian Pendapatan Asli Daerah di Kota Banda Aceh, menjelaskan bahwa setiap tahun PAD dan retribusi sampah mengalami peningkatan dan kontribusinya meningkatkan penerimaan pendapatan asli daerah kota banda aceh. Kemudian penelitian yang dilakukan oleh Jufaizal (2016) tentang Efektifitas Pelaksanaan Pemungutan Retribusi Sampah Kabupaten Rokan Hulu, menunjukan hasil yang efektif. Sedangkan menurut Ersita (2016) dalam penelitiannya yang menunjukan hasil efektivitas untuk retribusi daerah cukup efektif dalam kurun waktu 2011 sampai 2015, sedangkan kontribusinya terhadap PAD sedang namun rasio kontribusinya cenderung naik.

\section{METODE PENELITIAN}

Jenis Penelitian. Penelitian deskriptif kuantitatif adalah jenis penelitian yang digunakan di penelitian ini, tujuannya menjelaskan karakteristik dari suatu kelompok atau individu dengan menggunakan angka berdasarkan fenomena-fenomena sebagaimana yang terjadi.

Tempat \& Waktu Penelitian. Badan Keuangan Daerah atau BKD Kota Tomohon merupakan tempat pelaksanaan penelitian ini dan berlangsung sejak Juli 2018.

Jenis Data Penelitian. Data kualitatif yang dibutuhkan dalam penelitian ini berisi hasil wawancara, sejarah, visi dan misi, serta struktur organisasi BKD Kota Tomohon. Data kuantitatif dalam penelitian ini berupa data Retribusi Persampahan tahun 2015 sampai 2017, dan data Pendapatan Asli Daerah tahun 2015 sampai tahun 2017.

Sumber Data Penelitian. Wawancara dan dokumentasi dari Badan Keuangan Daerah Kota Tomohon merupakan sumber data primer yang diperlukan dalam penelitian ini.

\section{Metode Pengumpulan Data}

1. Wawancara. Wawancara akan dilakukan oleh peneliti dengan kepala sub bidang dan pegawai perencanaan pajak dan retribusi daerah Badan Keuangan Daerah Kota Tomohon tentang retribusi persampahan Kota Tomohon.

2. Dokumentasi. Peneliti akan mengumpulkan semua dokumen yang berkaitan dengan objek penelitian pada Di Keuangan Daerah Kota Tomohon.

Metode dan Proses Analisis. Metode analisis deskriptif merupakan metode analisis data yang akan digunakan. Tujuan dari metode ini yakni untuk membandingkan, memberikan gambaran, dan menguraikan serta menjelaskan suatu bahan, bukti atau data lalu ditelaah, supaya kita dapat menghasilkan kesimpulan sesuai dengan data yang ada. Untuk mengetahui tingkat efektivitas, kontribusi, retribusi persampahan terhadap pendapatan asli daerah maka menggunakan rumus sebagai berikut:

a. Efektivitas Retribusi Persampahan

$$
\frac{\text { Realisasi retribusi }}{\text { Target realisasi retribusi }} \times 100 \%
$$

Sumber: Darise (2009) 
b. Kontribusi Retribusi Persampahan

$$
\operatorname{Pn}=\frac{\text { QXn }}{\text { QYn }}
$$

Sumber: Darise (2009)

Keterangan:

$\begin{array}{ll} & \text { :Kontribusi retribusi terhadap PAD } \\ \text { :target/realisasi retribusi } \\ \text { QY } & \text { :target/realisasi PAD } \\ \mathrm{n} & \text { :Tahun (Periode Tertentu) }\end{array}$

\section{HASIL PENELITIAN DAN PEMBAHASAN}

\subsection{Hasil Penelitian}

Kota Tomohon adalah salah satu kota di Provinsi Sulawesi Utara, Indonesia, yang resmi berdiri pada tanggal 4 Agustus 2003. Badan Keuangan Daerah (BKD) merupakan Instansi Pemerintah yang didirikan bersama dengan adanya Pemerintah Daerah yang pelaksanaannya diatur dengan Undang-Undang Nomor 10 tahun 2003 tanggal 27 Januari 2003, saat itu Badan Keuangan Daerah masih menggunakan nama Bagian Keuangan Setda Kota Tomohon.

Retribusi Persampahan Kota Tomohon. Peraturan daerah tentang retribusi persampahan Kota Tomohon sudah dikeluarkan tahun 2012, namun pada saat itu pemerintah kurang siap dalam pelaksanaannya. Baik itu sosialisasi kepada masyarakat, cara pemungutan iuran retribusi persampahan serta fasilitas dan infrastruktur dalam pengelolaan sampah. Hal ini mengakibatkan pemungutan retribusi persampahan Kota Tomohon efektif berlaku tahun 2015. Prosedur penagihan retribusi persampahan yaitu wajib retribusi yang menerima pelayanan persampahan yang sudah terdaftar, lalu Petugas Pemungut akan datang langsung ke tempat wajib retribusi untuk menagih iuran retribusi pelayanan persampahan yang akan ditagih setiap bulan. Kemudian wajib retribusi membayar iuran retribusi dan diberikan Kartu Pelanggan Retribusi. Kartu Pelanggan Retribusi ini dibuat 2 (dua) lembar, lembar ke-1 untuk wajib retribusi sedangkan lembar ke-2 untuk petugas pemungut. Lalu petugas pemungut menyetorkan seluruh hasil iuran retribusi ke Bendahara penerima, yang setiap bulannya menyampaikan laporan pertanggung jawaban ke Badan Keuangan Daerah Kota Tomohon.

Tabel 1. Target dan Realisasi Retribusi Persampahan Kota Tomohon Tahun 2015-2017

\begin{tabular}{lrrr}
\hline Tahun & $\begin{array}{r}\text { Target } \\
\text { (Rupiah) }\end{array}$ & $\begin{array}{r}\text { Realisasi } \\
\text { (Rupiah) }\end{array}$ & $\begin{array}{r}\text { Persentase } \\
(\%)\end{array}$ \\
\hline 2015 & 2.000 .000 .000 & 201.076 .316 & $10,05 \%$ \\
2016 & 2.000 .000 .000 & 119.270 .000 & $5,96 \%$ \\
2017 & 2.000 .000 .000 & 893.940 .000 & $44,69 \%$ \\
Rata-rata & & & $20,33 \%$ \\
\hline
\end{tabular}

Sumber: Badan Keuangan Daerah Kota Tomohon 2018

Tabel 2. Target dan Realisasi Retribusi Persampahan Kota Tomohon Tahun 2015-2017

\begin{tabular}{lrrr}
\hline \multicolumn{1}{c}{ Tahun } & $\begin{array}{r}\text { Target } \\
(\text { Rupiah) }\end{array}$ & $\begin{array}{r}\text { Realisasi } \\
\text { (Rupiah) }\end{array}$ & $\begin{array}{r}\text { Persentase } \\
(\%)\end{array}$ \\
\hline 2015 & 2.000 .000 .000 & 201.076 .316 & $10,05 \%$ \\
2016 & 2.000 .000 .000 & 119.270 .000 & $5,96 \%$ \\
2017 & 2.000 .000 .000 & 893.940 .000 & $44,69 \%$ \\
Rata-rata & & & $20,33 \%$ \\
\hline
\end{tabular}

Sumber: Badan Keuangan Daerah Kota Tomohon 2018 
Realisasi PAD Kota Tomohon:

Tabel 3. Target dan Realisasi Pendapatan Asli Daerah Kota Tomohon Tahun 2015-2017

\begin{tabular}{lrrr}
\hline \multicolumn{1}{c}{ Tahun } & $\begin{array}{r}\text { Target } \\
\text { (Rupiah) }\end{array}$ & $\begin{array}{r}\text { Realisasi } \\
\text { (Rupiah) }\end{array}$ & $\begin{array}{r}\text { Persentase } \\
(\mathbf{\%})\end{array}$ \\
\hline 2015 & 25.039 .931 .368 & 20.688 .883 .680 & $82,62 \%$ \\
2016 & 26.363 .043 .368 & 26.321 .670 .690 & $99,84 \%$ \\
2017 & 31.526 .132 .000 & 29.543 .783 .344 & $93,71 \%$ \\
Rata-rata & & & $92,05 \%$ \\
\hline
\end{tabular}

Sumber: Badan Keuangan Daerah Kota Tomohon 2018

4.2. Pembahasan

Efektivitas Retribusi Persampahan Kota Tomohon:

Tabel 4. Efektivitas Retribusi Persampahan Kota Tomohon Tahun 2015-2017

\begin{tabular}{crrrr}
\hline Tahun & $\begin{array}{r}\text { Target } \\
(\text { Rupiah) }\end{array}$ & $\begin{array}{r}\text { Realisasi } \\
(\text { Rupiah) }\end{array}$ & $\begin{array}{r}\text { Persentase } \\
\text { Efektivitas } \\
(\%)\end{array}$ & $\begin{array}{r}\text { Tingkat } \\
\text { Efektivitas } \\
(\%)\end{array}$ \\
\hline 2015 & 2.000 .000 .000 & 201.076 .316 & $10,05 \%$ & Tidak Efektif \\
2016 & 2.000 .000 .000 & 119.270 .000 & $5,96 \%$ & Tidak Efektif \\
2017 & 2.000 .000 .000 & 893.940 .000 & $44,69 \%$ & Tidak Efektif \\
\hline
\end{tabular}

Sumber: Data diolah 2018

Tingkat efektifitas penerimaan retribusi persampahan dikatakan fluktuatif karena mengalami penurunan kemudian peningkatan. Di tahun 2015 dan 2016 realisasinya sedikit dikarenakan minimnya petugas penagih retribusi sampah. Di 2 tahun ini rumah-rumah warga belum dijangkau karena fokus penagihan iuran hanya mencakup kantor dan tempat usaha, karena beban Iuran kantor dan tempat usaha cukup besar dan jumlahnya tidak terlalu banyak sehingga masih bisa dijangkau dua petugas. Sedangkan pada tahun 2017 mengalami peningkatan yang cukup signifikan realisasinya menjadi Rp. 893.940.000 atau 44,69\% (tidak efektif). Walaupun tidak efektif, tingkat efektifitas retribusi persampahan tahun 2017 merupakan yang terbesar selama kurun waktu 3 tahun terakhir. Di tahun 2017 terjadi peningkatan yang sangat besar karena pemerintah telah melalukan beberapa cara untuk meningkatkan realisasi retribusi persampahan.

\section{Kontribusi Retribusi Persampahan:}

Tabel 5. Target Kontribusi Retribusi Persampahan terhadap Pendapatan Asli Daerah Kota Tomohon Tahun 2015-2017

\begin{tabular}{lccr}
\hline Tahun & $\begin{array}{c}\text { Target Retribusi Persampahan } \\
\text { (Rupiah) }\end{array}$ & $\begin{array}{c}\text { Target PAD } \\
\text { (Rupiah) }\end{array}$ & $\begin{array}{c}\text { Persentase } \\
\text { Target Kontribusi } \\
(\%)\end{array}$ \\
\hline 2015 & 2.000 .000 .000 & 25.039 .931 .368 & $7,98 \%$ \\
2016 & 2.000 .000 .000 & 26.363 .043 .368 & $7,58 \%$ \\
2017 & 2.000 .000 .000 & 31.526 .132 .000 & $6,34 \%$ \\
Rata-rata & & & $7,30 \%$ \\
\hline
\end{tabular}

Sumber: Data diolah 2018 
Tabel 6. Realisasi Kontribusi Retribusi Persampahan Terhadap Pendapatan Asli Daerah Kota Tomohon Tahun 2015-2017

\begin{tabular}{cccr}
\hline Tahun & $\begin{array}{c}\text { Realisasi Retribusi Persampahan } \\
\text { (Rupiah) }\end{array}$ & $\begin{array}{c}\text { Realisasi PAD } \\
\text { (Rupiah) }\end{array}$ & $\begin{array}{c}\text { Persentase } \\
\text { Kontribusi } \\
(\%)\end{array}$ \\
\hline 2015 & 201.076 .316 & 20.688 .883 .680 & $0,97 \%$ \\
2016 & 119.270 .000 & 26.321 .670 .690 & $0,45 \%$ \\
2017 & \begin{tabular}{c}
893.940 .000 \\
\multicolumn{2}{c}{ Rata-rata }
\end{tabular} & 29.543 .783 .344 & $3,02 \%$ \\
& & & $1,48 \%$ \\
\hline
\end{tabular}

Sumber: Data diolah 2018

Berdasarkan hasil perhitungan diatas, dapat dilihat bahwa penerimaan retribusi persampahan dari tahun ke tahun mengalami perubahan. Pada tahun 2015 kontribusi retribusi persampahan terhadap PAD Kota Tomohon sebesar 0,97\% dari target kontribusinya 7,98 \%. Lalu pada tahun 2016 dari target kontribusi sebesar 7,58 \% kontribusinya turun menjadi 0,45\%. Kemudian tahun 2017 meningkat menjadi 3.02\% dari target sebesar 6,34\%. Target ini menurun karena target PAD meningkat namun target retribusi persampahan masih sama seperti tahun sebelumnya, namun penerimaan retribusi persampahan meningkat tajam.

\section{KESIMPULAN DAN SARAN}

\subsection{Kesimpulan.}

1. Tingkat efektifitas retribusi persampahan tahun 2015 sebesar 10,05\% (tidak efektif). Kemudian di tahun 2016 tingkat efektivitasnya mengalami penurunan menjadi 5,96\% (tidak efektif). Tetapi pada tahun 2017 tingkat tingkat efektivitasnya meningkat tajam menjadi 44,69\%. Walaupun tidak efektif, namun pada tahun 2017 merupakan tingkat efektivitas tertinggi selama 3 tahun Perda ini efektif diberlakukan. Jadi, tingkat efektivitas penerimaan retribusi persampahan berfluktuatif selama 3 tahun berjalan, ditahun awal mengalami penurunan, namun ditahun berikutnya mengalami peningkatan.

2. Kontribusi retribusi persampahan terhadap Pendapatan Asli Daerah Kota Tomohon selama 3 tahun rata-rata sebesar 1,48\%. Jumlah ini masih dibilang kecil dari target 7,30 $\%$. Jumlah ini bisa dibilang sangat kecil, namun cukup berguna dalam pembiayaan pemerintah.

\subsection{Saran}

Bagi pemerintah Kota Tomohon diharapkan dapat mengevaluasi atau mengkaji ulang sistem pemungutan yang ada, menambah dan memperbaiki infrastruktur dalam pengelolaan sampah, lebih tegas dalam pemberian sanksi, serta sosialisasi harus digalakan. Juga untuk masyarakat harus memiliki kesadaran untuk membayar retribusi tepat pada waktunya. Dengan demikian maka penerimaan retribusi persampahan semakin besar, serta dapat memberikat kontribusi yang lebih besar terhadap Pendapatan Asli Daerah.

\section{DAFTAR PUSTAKA}

Agoes, Estralita. 2013. Akuntansi Perpajakan, Edisi 3. Salemba Empat. Jakarta.

Agoes, Sukrisno. 2014. Auditing Petunjuk Praktis Pemeriksaan Akuntan oleh Akuntan Publik. Edisi ke 4. Buku 1. Salemba Empat. Jakarta.

Ersita. 2016. Analisis Efektivitas Penerimaan Retribusi Daerah Dan Kontribusinya Terhadap Peningkatan Pendapatan Asli Daerah (PAD) Di Provinsi Sulawesi Utara. Jurnal EMBA Vol.4 No.1. Manado. Fakultas Ekonomi dan Bisnis Universitas Sam Ratulangi Manado. 
Halim, A. Kusufi, S. 2012. Akuntansi Sektor Publik: teori, konsep dan aplikasi. Salemba Empat. Jakarta.

Handoko, 2013. Manajemen; Edisi Kedua, Cetakan Ketigabelas. BPFE Yogyakarta.

Jufaizal. 2016. Analisis Efektifitas Pelaksanaan Pemungutan Retribusi Sampah Kabupaten Rokan Hulu. Skripsi. Rokan Hulu. Fakultas Ekonomi Universitas Pasir Pengaraian.

Kartikahadi, H. dkk. 2016. Akuntansi Keuangan Berdasarkan SAK Berbasis IFRS Buku 1. Salemba Empat. Jakarta.

Mahmudi. 2016. Analisis Laporan Keuangan Pemerintah Daerah. Edisi Ketiga. Unit Penerbit Dan Percetakan Sekolah Tinggi Ilmu Manajemen YKPN. Yogyakarta.

Mardiasmo. 2016. Perpajakan. Edisi Revisi 2016. Penerbit Andi. Yogyakarta.

Mosal. 2013. Analisis Efektivitas Kontribusi Pajak Parkir Terhadap Pendapatan Asli Daerah (PAD) Dan Penerapan Akuntansi Di Kota Manado. Jurnal EMBA Vol.1 No.4. Manado. Fakultas Ekonomi dan Bisnis Universitas Sam Ratulangi Manado.

Pemerintah Kota Tomohon. 2012. Peraturan Daerah Kota Tomohon Nomor 8 Tahun 2012. Tomohon

Puspitasari. 2014. Analisis Efektivitas, Efisiensi, Dan Kontribusi Pajak Dan Retribusi Daerah Terhadap PAD Kabupaten Blora Tahun 2009-2011. Skripsi. Semarang. Fakultas Ekonomika Dan Bisnis Universitas Diponegoro.

Resmi, S. 2014. Perpajakan Teori dan Kasus. Edisi Keempat. Salemba Empat. Jakarta.

Saifullah. 2016. Efektifitas Peningkatan Retribusi Sampah Terhadap Pencapaian Pendapatan Asli Daerah Di Kota Banda Aceh. Jurnal. Banda Aceh. Pendidikan Ekonomi Universitas Serambi Mekkah.

Sari, D. 2013. Konsep Dasar Akuntansi Perpajakan. Refika Aditama. Bandung.

Undang-Undang Republik Indonesia Nomor 28 Tahun 2009. Pajak Daerah dan Retribusi Daerah. Lembaran Negara Republik Indonesia Tahun 2009 Nomor 130. Jakarta.

Undang-Undang Republik Indonesia Nomor 33 Tahun 2004. Perimbangan Keuangan Antara Pemerintah Pusat dan Daerah. Lembaran Negara Republik Indonesia Tahun 2004 Nomor 126. Jakarta.

Waluyo. 2013. Perpajakan Indonesia. Salemba Empat. Jakarta.

Warren. 2014. Pengantar Akuntansi Adaptasi Indonesia. Salemba Empat. Jakarta.

Yuliastuti. 2013. Partisipasi Masyarakat Dalam Pengelolaan Sampah Di Kabupaten Badung. Jurnal. Bali. Fakultas Ekonomi Universitas Udayana Bali. 